\title{
ANALISIS KINERJA PERUSAHAAN BERDASARKAN LAPORAN ARUS KAS PADA PT INDOMOBIL SUKSES INTERNASIONAL TBK
}

\author{
Arief Tri Hardiyanto ${ }^{*}$ dan Stefan Michael Benyamin Bertus ${ }^{* *}$
}

\begin{abstract}
ABSTRAK
Penelitian ini membahas peranan analisis laporan arus kas sebagai penunjang evaluasi kinerja perusahaan berdasarkan rasio arus kas, sehingga dapat dilihat kemampuan perusahaan dalam mengelola kas, baik untuk aktivitas operasi, aktivitas investasi, maupun aktivitas pendanaan. Analisis tersebut diharapkan berguna sebagai salah satu perangkat penunjang dalam proses pengambilan keputusan bagi para pemakai laporan keuangan baik bagi pihak internal maupun eksternal perusahaan. Berdasarkan analisis pola arus kas, dapat diketahui aktivitas operasi perusahaan menghasilkan net cash yang bernilai negatif. Dengan demikian kondisi keuangan PT Indomobil Sukses Internasional Tbk adalah tidak baik. Arus kas dari aktivitas investasi memberikan hasil yang negatif, Dengan demikian kondisi keuangan PT Indomobil Sukses Internasional Tbk adalah baik Arus kas pendanaan menghasilkan jumlah arus kas bersih yang bernilai positif. Dari penjelasan ketiga pola arus kas, maka dapat disimpulkan bahwa kondisi keuangan PT Indomobil Sukses Internasional Tbk secara umum dalam kondisi kurang baik. Kemudian, berdasarkan analisis laporan arus kas, diperoleh informasi bahwa perusahaan memiliki tingkat likuiditas dan solvabilitas yang kurang baik. Struktur modal perusahaan belum cukup efektif dan efisien.
\end{abstract}

Kata Kunci: Analisis Laporan Arus Kas

\section{Abstract}

This research discusses the role of the analysis of the cash flow statement as supporting the evaluation of company performance based on cash flow ratio, so that it can be seen in the company's ability to manage cash, either in operating activities, investing activities, and financing activities. The analysis is expected to be useful as a supporting device in the decision making process for users of financial statements for both internal and external parties. Based on the analysis of the cash flow pattern, it can be seen operating activities resulted in net cash the company is negative. Thus the financial condition of PT Indomobil Sukses Internasional Tbk is not good. Cash flows from investing activities yielded negative results, thus the financial condition of PT Indomobil Sukses Internasional Tbk is both a financing cash flow generating net amount of cash flow that is positive. The third explanation pattern of cash flow, it can be concluded that the financial condition of PT Indomobil Sukses Internasional Tbk generally in poor condition. Then, based on the analysis of the cash flow statement, author obtained information that the company has liquidity and solvency levels that are less good. The capital structure of the company has not been sufficiently effective and efficient.

Keywords: Analysis of Cash Flow Statement

\footnotetext{
${ }^{*}$ Dosen Tetap Fakultas Ekonomi Universitas Pakuan

${ }^{* *}$ Mahasiswa Fakultas Ekonomi Universitas Pakuan

JIAFE (Jurnal Ilmiah Akuntansi Fakultas Ekonomi)

Volume 1 No. 2 Tahun 2015, Hal. 63-76
} 


\section{Pendahuluan}

$\begin{array}{ccc}\text { Tujuan } & \text { utama dari } & \text { suatu } \\ \text { perusahaan } & \text { adalah } & \text { untuk }\end{array}$ memaksimalisasikan nilai perusahaan yaitu dengan memaksimumkan laba atau keuntungan. Kemampuan perusahaan dalam menghasilkan keuntungan adalah kunci keberhasilan perusahaan untuk mempunyai kinerja perusahaan yang baik. Demi tercapainya tujuan tersebut, perusahaan perlu melakukan analisis laporan keuangan agar dapat mengetahui apakah perusahaan sudah berjalan dengan efektif dan efisien. Analisis laporan keuangan merupakan salah satu alat yang digunakan oleh manajer untuk mencapai maksimalisasi nilai perusahaan tersebut.

Perusahaan perlu melakukan analisis laporan keuangan karena laporan keuangan digunakan untuk menilai kinerja perusahaan, dan digunakan untuk melihat apakah perusahaan tersebut meningkat atau tidak sehingga perusahaan mempertimbangkan keputusan yang akan diambil untuk tahun yang akan datang sesuai dengan kinerja perusahaannya. Kinerja adalah sesuatu yang ingin dicapai, untuk melakukan sesuatu yang ingin dicapai oleh seseorang. Jadi kinerja perusahaan adalah proses pengkajian secara kritis terhadap keuangan perusahaan untuk memberikan solusi dalam pengambilan suatu keputusan yang tepat pada suatu periode tertentu.

Hasil analisis laporan keuangan dapat digunakan oleh pihak internal maupun eksternal perusahaan. Pihak intern ini adalah mereka yang diberi tanggung jawab untuk melaksanakan kegiatan perusahaan, seringkali disebut sebagai manajemen. Manajemen memiliki kontrol pada sistem akuntansi dan dapat menjelaskan secara rinci informasi yang dibutuhkan dan dilaporkan. Sedangkan pihak ekstern itu adalah pihak yang berasal dari luar lingkungan perusahaan yang mempunyai kepentingan terhadap perusahaan, seperti pemegang usaha, para investor, kreditor, pemerintah, masyarakat umum, pemasok, pelanggan, dan karyawan.

Sampai saat ini, para pemakai laporan keuangan terbiasa mengandalkan data dari laporan posisi keuangan dan laporan laba rugi sebagai dasar untuk pengambilan keputusan. Padahal, kas merupakan salah satu sumber daya penting yang dibutuhkan oleh perusahaan untuk kegiatan operasinya. Kas akan membuat suatu perusahaan dapat bertahan dan melangsungkan kehidupannya, sesuai dengan prinsip going concern. Analisis arus kas membantu kita mengevaluasi kinerja perusahaan dengan menilai likuiditas, solvabilitas, dan fleksibilitas keuangan perusahaan tersebut.

Menurut Simamora (2002) laporan arus kas (statement of cash flow) memperlihatkan aktivitas-aktivitas operasi, investasi dan pendanaan perusahaan mempengaruhi kas selama satu periode akuntansi. Menurut Franklin J. Plewa, Jr \& George T. Friedlob (1995) dalam buku yang berjudul Understanding Cash Flow, analisis laporan arus kas untuk menilai kinerja keuangan perusahaan dapat menggunakan rasio arus kas yang terbagi atas tiga bagian utama yaitu, menilai kinerja dengan liquidity and solvency ratios, capital expenditure and investing ratios, and cash flow return ratios.

Menurut James D. Stice, Earl K. Stice dan K. Fred Skousen $(2009,304)$ pemahaman yang berguna tentang perusahaan mungkin diperoleh dengan menganalisis hubungan antara tiga kategori arus kas. Pola-pola arus kas ini menekankan pentingnya arus kas 
operasi. Dengan memperhatikan beberapa pola aliran kas maka dapat diketahui makna dari informasi arus kas dari suatu perusahaan yang dilaporkan dalam laporan arus kas sehingga dapat mengevaluasi pengelolaan kas yang dilakukan perusahaan.

Laporan posisi keuangan, laporan laba rugi komprehensif dan laporan arus kas merupakan laporan yang terintegrasi, sehingga dalam melakukan analisis laporan keuangan ketiga laporan ini akan saling terkait. Oleh karena itu, dengan mengikutsertakan analisis laporan arus kas, maka investor dan kreditor akan mendapatkan informasi tambahan mengenai kinerja keuangan yang dihasilkan perusahaan. Informasi tambahan ini sekaligus menjadi informasi pendukung bagi manajemen perusahaan dalam pengambilan keputusan.

Penelitian tentang analisis kinerja perusahaan berdasarkan laporan arus kas telah banyak dilakukan oleh penelitian terdahulu antara lain; penelitian yang dilakukan oleh Andra Kusumadiyanto universitas Widyatama Bandung (2006) yang berjudul “

Analisis Laporan Keuangan Untuk Menilai Kinerja Perusahaan Pada Kelompok Industri Rokok". Hasil penelitian menunjukkan adanya penurunan kinerja perusahaan, dan Andika Febriani Universitas Katolik Indonesia Atmajaya Jakarta (2009), yang mengambil judul "Analisis Kemampuan Prediksi Laporan Arus Kas Dan Kinerja Perusahaan Berdasarkan Rasio Keuangan: Studi Kasus Pada PT Exelcomindo Pratama Tbk". Hasil penelitian menunjukan bahwa, perubahan arus kas perusahaan tidak berpengaruh terhadap perubahan laba perusahaan.

Berdasarkan latar belakang di atas, maka penulis tertarik untuk menganalisa laporan arus kas untuk menilai kinerja perusahaan PT Indomobil Sukses Internasional Tbk.

Adapun tujuan penelitian ini adalah: 1) Untuk melihat kinerja keuangan PT Indomobil Sukses Internasional Tbk berdasarkan hasil analisis pola arus kas; 2) Untuk mengetahui apakah evaluasi terhadap laporan arus kas dapat mencerminkan sehat atau tidaknya kinerja keuangan PT Indomobil Sukses Internasional Tbk; dan 3) Untuk mengetahui apakah evaluasi terhadap laporan arus kas dapat membantu pihak manajemen perusahaan dalam melakukan pengambilan keputusan, yang berkaitan dengan kelangsungan hidup PT Indomobil Sukses Internasional Tbk.

\section{Landasan Teori}

\subsection{Pengertian Kas}

Kas merupakan komponen aktiva (aset) lancar yang paling likuid di dalam neraca, karena kas sering mengalami mutasi atau perpindahan dan hampir semua transaksi yang terjadi dalam perusahaan akan mempengaruhi posisi kas. Menurut Stice dan Skousen (2005 : 495) mendefenisikan kas adalah "Aktiva Lancar yang paling likuid dan terdiri dari bagian yang bertindak sebagai alat pertukaran serta memberikan dasar untuk perhitungan akuntansi". Dari defenisi diatas dapat diketahui yang termasuk kas adalah aktiva lancar paling likuid berupa uang yang tersimpan pada perusahaan atau luar perusahaan misalnya bank, yang akan digunakan sebagai alat pembayaran oleh perusahaan.

\subsection{Pengertian Laporan Arus Kas}

Definisi laporan arus kas menurut Henry Simamora (2001 : 488), "Laporan arus kas (Cash Flow Statement)adalah laporan keuangan yang memperlihatkan pengaruh dari aktivitas-aktivitas operasi, investasi, dan 
pendanaan perusahaan terhadap arus kas selama periode akuntansi tertentu dalam suatu cara merekonsiliasi saldo awal dan akhir kas".

\subsection{Tujuan Arus Kas}

Menurut Horngren, Harrison, Robinson, dan Secokusumo (2003 : 845), arus kas dirancang untuk memenuhi tujuan-tujuan berikut ini :

1. Untuk memperkirakan arus kas dimasa yang akan datang. Kas dan bukan laba akuntansi yang digunakan untuk pembayaran tagihan. Dalam banyak kasus, sumber dan penggunaan kas perusahaan tidaklah berubah secara dramatis dari tahun ke tahun. Karena itu penerimaan dan pengeluaran kas dapat diterima sebagai alat yang baik untuk memperkirakan penerimaan dan pengeluaran kas dimasa datang.

2. Untuk mengevaluasi keputusan manajemen. Jika manajer membuat keputusan investasi yang bijaksana, maka perusahaannya akan sejahtera. Tetapi jika manajer membuat keputusan yang tidak bijaksana, maka perusahaan akan menderita karenanya. Laporan arus kas akan melaporkan kegiatan investasi perusahaan sehingga memberikan informasi arus kas kepada investor dan kreditor untuk mengevaluasi keputusan manajer.

3. Untuk menentukan kemampuan perusahaan membayar deviden pada pemegang saham, pembayaran bunga, dan pokok pinjaman pada kreditor. Pemegang saham tertarik padapenerimaan deviden dari investasinya dalam saham perusahaan. Kreditor ingin menerima bunga dan pokok pinjamannya tepat waktu.
Laporan arus kas kepada investor dan kreditor untukmengetahui apakah perusahaan bisa melakukan pembayaranpembayaran ini.

4. Untuk menunjukkan hubungan laba bersih terhadap perubahan arus kas perusahaan. Biasanya kas dan laba bersih bergerak bersama. Tingginya tingkat laba cenderung menyebabkan peningkatan kas dan sebaliknya. Akan tetapi nilai sisa kas menurun ketika laba bersih tinggi dan kas bisa meningkat ketika laba bersih rendah. Adanya kemungkinan bangkrutnya suatu perusahaan yang mempunyai laba bersih yang cukup tetapi kas yang rendah, menyebabkan diperlukannya informasi arus kas.

\subsection{Kegunaan Arus Kas}

Menurut Standar Akuntansi Keuangan (IAI) No.2 (2007 : 2.1), kegunaan laporan arus kas yaitu: Jika digunakan dalam kaitannya dengan laporan keuangan lain, laporan arus kas dapat memberikan informasi yang memungkinkan para pemakai untuk mengevaluasi perubahan dalam aktiva bersih, struktur keuangan (termasuk likuiditas dan solvabilitas) dan kemampuan untuk mempengaruhi jumlah serta waktu arus kas dalam rangka adaptasi dengan perubahan keadaan dan peluang. Informasi arus kas berguna untuk menilai kemampuan perusahaan dalam menghasilkan kas dan setara kas dan memungkinkan para pemakai mengembangkan model untuk menilai dan membandingkan nilai sekarang dari arus kas masa depan (future cash flows)dari berbagai perusahaan. Informasi tersebut juga meningkatkan daya banding pelaporan kinerja operasi berbagai perusahaan karena dapat meniadakan pengaruh 
penggunaan perlakuan akuntansi yang berbeda terhadap transaksi dan peristiwa yang sama.

\subsection{Format Laporan Arus Kas}

Penerimaan kas dan pengeluaran kas dalam suatu periode diklasifikasikan dalam tiga aktivitas yaitu :

1. Arus kas dari aktivitas operasi

Semua transaksi yang berkaitan dengan laba yang dilaporkan dalam laporan laba rugi dikelompokkan dalam aktivitas operasi. Berikut beberapa contoh arus kas yang berasal dari aktivitas operasi baik arus kas masuk (cash inflows) maupun arus kas keluar (cash outflows):

Arus kas masuk, antara lain: a) Penerimaan kas dari pelanggan (penjualan barang atau penyerahan jasa); b) Penerimaan kas dari pemberian pinjaman (bunga yang diterima); c) Penerimaan kas dari ekuitas surat berharga (deviden yang diterima); d) Semua penerimaan yang bukan berasal dari sebagian yang sudah dimasukkan dalam kelompok investasi dan pembiayaan, serta jumlah uang yang diterima dari tuntutan pengadilan, klaim asuransi, kecuali yang lansung berhubungan dengan kegiatan investasi dan pembiayaan seperti kerusakan gedung.

Arus kas keluar antara lain: a) Pembayaran kas untuk pembelian bahan yang akan digunakan untuk dijual atau produksi termasuk pembayaran utang jangka pendek; b) Pembayaran kepada supplier lain dan pegawai untuk kegiatan selain produksi barang dan jasa; c) Pembayaran kas kepada pemerintah untuk pajak, kewajiban lainnya, denda,dan lain-lain; d) Pembayaran kepada pemberi pinjamandan kreditur lainnya berupa bunga; e) Seluruh pembayaran kas yang tidak berasal dari transaksi investasi atau pembiayaan seperti pembayaran tuntutan dipengadilan, pengembalian dana kepada langganan dan sumbangan.

2. Arus kas dari aktivitas investasi Aktivitas investasi merupakan perolehan dan pelepasan aktiva jangka panjang serta investasi lain yang tidak termasuk setara kas. Pengungkapan terpisah arus kas yang berasal dari aktivitas investasi perlu dilakukan sebab arus kas tersebut mencerminkan penerimaan dan pengeluaran kas sehubungan dengan sumber daya yang bertujuan untuk menghasilkan pandapatan dan arus kas dimasa depan. Berikut beberapa contoh arus kas yang berasal dari aktivitas investasi, baik arus kas masuk (cash inflows) maupun kas keluar (cash outflows). Arus kas masuk antara lain: a) Penerimaan kas dari penagihan piutang jangka panjang; b) Penerimaan kas dari penjualan surat berharga yang berupa investasi jangka panjang; c) Penerimaan kas dari penjualan aktiva tetap, aktiva tidak berwujud, dan aktiva jangka panjang.

Arus kas keluar antara lain: a) Pembayaran kas untuk pembelian aktiva tetap dan aktiva jangka panjang lainnya; b) Pembayaran kas untuk pembelian surat berharga perusahaan yang berupa investasi jangka panjang; c) Pembayaran kas untuk aktiva tidak berwujud. Beberapa transaksi seperti penjualan aktiva 
tetap dapat menimbulkan keuntungan ataupun kerugian yang dimasukkan dalam perhitungan laba rugi bersih. Transaksi ini harus dimasukkan dalam klasifikasi arus kas dari kegiatan investasi.

3. Arus kas dari aktivitas pendanaan Aktivitas pendanaan adalah aktivitasyang mengakibatkan perubahan dalam jumlah serta komposisi modal dan pinjamanperusahaan. Arus kas dari aktivitas pendanaan ini harus diungkapkan terpisah, kerena pengungkapan terpisah arus kas dari aktivitas pendanaan berguna untuk memprediksi klaim atas arus kas masa depan oleh para penanam modal di perusahaan tersebut. Kegiatan pendanaan melibatkan upaya-upaya untuk memperoleh dana selaku peminjam atau penerbit sekuritas dan membayar kembali pinjaman atau sekuritas kepemilikan tersebut. Arus kas masuk dari aktivitas pendanaan antara lain: a) Penerimaan kas dari penjualan surat berharga; b) Penerimaan kas dari pemberian pinjaman kreditur; c) Penerimaan kas dari penerbitan saham; d) Penerimaan kas dari penerbitan kewajiban jangka panjang.

Arus kas keluar antara lain: a) Pembayaran kas kepada para pemegang saham dalam bentuk deviden; b) Pembayaran kas untuk penebusan kewajiban jangka panjang; c) Pembayaran kas untuk memperoleh kembali sekuritas ekuitas (termasuk pembelian saham tresuri).

\subsection{Pengertian Analisis Laporan Keuangan}

Analisis laporan keuangan terdiri dari dua kata, analisis dan laporan keuangan. Untuk menjelaskan pengertian kata ini maka dapat dilihat dari arti masing-masing kata. Menurut Kamus Besar Bahasa Indonesia Analisis adalah penguraian suatu pokok atas berbagai bagiannya dan penelaahan bagian itu sendiri, serta hubungan antar bagian untuk memperoleh pengertian yang tepat dan pemahaman arti keseluruhan.

Sedangkan laporan keuangan menurut IAI (2007 : 1), "Laporan keuangan merupakan bagian dari proses pelaporan keuangan. Laporan keuangan yang lengkap meliputi neraca, laporan rugi laba, laporan perubahan posisi keuangan, Catatan dan Laporan lain serta materi penjelasan yang merupakan bagian integral dari laporan keuangan".

Menurut Sofyan Syafri Harahap (2006 : 190), ada beberapa pengertian dari analisis laporan keuangan yang dijelaskan oleh para ahli antara lain :

a. Berstein menjelaskan bahwa pengertian dari analisis laporan keuangan adalah: "Analisis laporan keuangan mencakup penerapan metode dan teknik analitis atas laporan keuangan dan data lainnya untuk melihat darilaporan keuangan itu ukuranukuran dan hubungan tertentu yang sangat berguna dalam proses pengambilan keputusan”. "Laporan keuangan ini merupakan kebalikan dari kegiatan pembukuan. Kalau proses pembukuan dimulai dari transaksi, dicatat kebuku, diproses dan akhirnya menjadi laporan keuangan, maka dalam analisis laporan keuangan kegiatan dimulai dari laporan keuangan, ditelusuri kebuku, sampai ketransaksi perusahaan". 
b. Foster mengemukakan pengertian analisis laporan keuangan sebagai berikut: "Mempelajari hubunganhubungan didalam surat set laporan keuangan pada suatu saat tertentu dan kecenderungankecenderungan dari hubungan ini sepanjang waktu".

c. Helfert dalam kata pendahuluannya, walaupun tidak merupakan defenisi eksplisit tetapi terkandung makna bahwa Analisa Laporan Keuangan adalah : "Merupakan alat yang digunakan dalam memahami masalah dan peluang yang terdapat dalam laporan keuangan." Ia juga menekankan bahwa : "Analisis Laporan Keuangan adalah pada arus dana dalam suatu sistem bisnis. Dari gambaran arus dana ini dapat dilihat prestasi perusahaan, proyeksi, optimalisasi modal, dan sumber dana perusahaan".

Dan dari berbagai pengertian diatas, penulis menyimpulkan bahwa pengertian dari analisis laporan keuangan adalah suatu alat yang dapat digunakan untuk memahami hubunganhubungan yang terdapat dalam laporan keuangan pada suatu saat tertentu dan kecenderungan-kecenderungannya.

\section{Metode Penelitian}

Metode analisis adalah suatu proses penyederhanaan data ke dalam bentuk yang lebih mudah untuk dibaca dan diinterprestasikan dalam menganalisis permasalahan yang diangkat serta melihat hubungan antara variabel-variabel yang terkait. Dalam penelitian ini penulis menggunakan metode analisis Deskriptif Kualitatif (non-statistik), yaitu menggambarkan kondisi yang sedang terjadi dengan kriteria yang seharusnya terjadi, dikumpulkan, disusun, serta dipelajari dan dianalisis lebih lanjut mengenai analisis arus kas yang diindikasikan dapat mempengaruhi peningkatan kinerja keuangan. Data yang diperoleh adalah data yang diperoleh dari laporan keuangan PT Indomobil Sukses Internasional, Tbk.

\section{Hasil dan Pembahasan \\ 4.1. Analisis Arus Kas}

Berdasarkan informasi yang diperoleh dari laporan posisi keuangan, laporan laba rugi komprehensif, dan laporan arus kas, maka analisis rasio dari laporan arus kas dapat digunakan sebagai informasi untuk menilai kinerja perusahaan. Rasio arus kas yang dimaksud adalah:

1. Liquidity ratios

2. Solvency ratios

3. Investing ratio

4. Cash flow return ratios

\section{Liquidity ratios}

Liquidity ratios adalah laporan arus kas yang berfungsi untuk mengukur kemampuan perseroan dalam membayar hutang jangka pendeknya. Liquidity ratios terdiri dari:

\section{a. Current Cash Debt Coverage Rasio}

Pada tahun 2011 sampai tahun 2013 di atas menunjukan perusahaan tidak mampu menjamin setiap rupiah kewajiban jangka pendeknya karena rasio yang dihasilkan negatif. Perusahaan juga tidak mempunyai kemampuan dalam menjamin kewajiban lancarnya karena arus kas dari aktivitas operasi bernilai negatif, artinya kas yang masuk lebih sedikit daripada arus kas yang keluar. Peningkatan jumlah kewajiban lancar tiap tahunnya terjadi karena adanya pinjaman dari bank, hutang usaha, hutang lain-lain dan hutang pajak selama tahun berjalan. 


\section{b. Cash Dividend Coverage Ratio}

Di tahun 2011, perseroan tidak memiliki kemampuan yang baik dalam membayar deviden kepada para pemegang saham. Ini dibuktikan dengan rasio yang diperoleh sebesar - 37,97 kali. Pada tahun 2012, meskipun perusahaan dalam membayar deviden meningkat sangat besar menjadi - 16,58 kali. Tetapi di tahun 2013, kemampuan perusahaan mengalami penurunan kembali dalam membayar deviden dengan rasio sebesar - 27,93 kali.

Dengan demikian, perusahaan belum memiliki tingkat likuiditas yang baik karena tidak mampu membayar deviden kepada para pemegang saham dengan mengandalkan jumlah arus kas bersih yang dihasilkan oleh aktivitas operasi.

\section{Solvency ratios}

Selain melihat kemampuan perusahaan dalam menyelesaikan kewajiban jangka pendeknya, perlu juga dianalisis kemampuan perusahaan dalam memenuhi kewajiban jangka panjang di masa yang akan datang (beserta beban bunga yang harus dibayar secara periodik), dengan menggunakan kas yang dihasilkan oleh aktivitas operasi perusahaan. Adapun rasio yang digunakan untuk melihat tingkat solvabilitas perusahaan adalah:

\section{a. Cash Debt Coverage Ratio}

Rasio perhitungan 2011 sampai dengan tahun 2013 di atas menunjukan bahwa perusahaan memiliki kemampuan yang kurang baik dalam melunasi seluruh kewajibannya dengan menggunakan arus kas bersih yang dihasilkan oleh aktivitas operasinya. Karena arus kas dari aktivitas operasi adalah negatif yang artinya arus kas keluar lebih besar daripada arus kas masuk.

\section{b. Cash Interest Coverage Ratio}

Rasio perhitungan dari tahun 2012 sampai dengan tahun 2013 di atas menunjukkan bahwa perusahaan tidak mampu menutup beban bunga karena arus kas bersih yang dihasilkan dari kegiatan operasi bertanda negatif.

\section{Investment Ratios}

Rasio ini penting bagi investor dan kreditor dalam kaitannya untuk memberikan informasi mengenai tingkat pertumbuhan yang dialami perusahaan. Untuk mengukur sejauh mana kemampuan perusahaan dalam menutup semua pengeluaran yang berkaitan dengan pembiayaanpembiayaan aktiva tetap maka perlu dihitung rasio-rasio berikut:

\section{a. Cash Flow from Operating Activities Plus Finance Ratio \\ Dari perhitungan dari tahun} 2011 sampai dengan tahun 2013 di atas, menunjukkan bahwa keadaan ini menandakan bahwa perusahaan dalam keadaan yang kurang baik, karena hasil rasio yang didapat adalah negatif. Dalam rasio ini, semakin besar rasio menunjukan semakin besar pula investasi dalam bentuk aktiva tetap yang dibiayai oleh aktivitas operasi dan aktivitas pendanaan.

\section{b. Investment Ratio}

Perhitungan rasio dari tahun 2011 sampai dengan tahun 2013 diatas menunjukan bahwa perusahaan belum layak untuk melakukan investasi dalam aktiva tetap dengan menggunakan arus kas yang dihasilkan oleh aktiva operasi perusahaan. Hal ini disebabkan oleh arus kas yang dihasilkan oleh aktivitas operasi mempunyai jumlah yang lebih kecil daripada arus kas yang digunakan oleh aktivitas investasi.

\section{Cash Flow Return Ratios}


Rasio arus kas ini berguna bagi para investor dan kreditor dalam hal mengukur kemampuan perusahaan untuk menghasilkan laba. Bagi perusahaan, laba operasi ini penting untuk menjaga kelanjutan usaha perusahaan. Para investor berkepentingan terhadap laba perusahaan untuk memprediksi jumlah deviden yang akan diperohlehnya pada periode tertentu. Sedangkan, para kreditor berkepentingan terhadap laba perusahaan untuk melihat apakah perusahaan mampu membayar hutang yang ada dengan laba yang diperolehnya.

Untuk melihat kemampuan perusahaan dalam memberikan keuntungan bagi para penanam modal, maka berikut ini adalah rasio-rasio profabilitas yang dihasilkan perusahaan dari tahun 2011 sampai tahun 2013:

\section{a. Overall Cash Flow Ratio}

Perhitungan rasio dari tahun 2011 sampai dengan tahun 2013 di atas menunjukan arus kas bersih yang berasal dari aktivitas operasi bernilai negatif. Keadaan ini menunjukan bahwa perusahaan menghasilkan arus kas yang berasal dari aktivitas operasi lebih sedikit jika dibandingkan dengan jumlah kas yang dibutuhkan oleh aktivitas investasi dan pendanaan.

Dalam keadaan seperti ini, perusahaan mengalami kekurangan kas yang berasal dari aktivitas operasi.

\section{b. Cash Return on Sales Ratio}

Dari analisis diatas diketahui bahwa dari tahun 2011 sampai dengan tahun 2013 terjadi fluktuatif. Pada tahun 2011 perusahaan mampu mengubah $-8 \%$ dari seluruh penerimaannya yang bersifat akrual menjadi uang kas. Sedangkan, di tahun 2012, kemampuan perusahaan menurun menjadi $-14 \%$ dan di tahun
2013 mengalami kenaikan. Kenaikan ini terjadi karena, perusahaan mampu meningkatkan penjualan tahun 2013, dan jumlah kas dikumpulkan perusahaan melalui aktivitas operasi mengalami kenaikan. Akan tetapi hasil rasio yang dihasilkan adalah negatif. Maka kemampuan perusahaan dalam mengubah penerimaan berdasarkan akrual menjadi uang kas tidak baik.

Agar kinerja perusahaan dapat dipertahankan, atau bahkan diharapkan mengalami peningkatan di tahun mendatang dengan memberikan return yang lebih baik, perusahaan harus meningkatkan jumlah arus kas bersih yang dihasilkan oleh aktivitas operasi. Walaupun bila dilihat dari arus kas keluar yang dialami perusahaan, tercermin bahwa perusahaan tidak cukup efisien dalam menangani semua biaya yang dikeluarkannya. Terjadi peningkatan jumlah beban yang harus dibayar dengan kas dalam jumlah yang signifikan di tahun 2012 dan 2013.

Tetapi dilihat dari jumlah kas yang dikumpulkan perusahaan dari para pelanggan, perusahaan mempunyai kemampuan yang baik dalam menagih kas dari setiap transaksi penjualan yang terjadi.

Oleh karena itu, usaha yang harus dilakukan perusahaan agar kinerja keuangannya menjadi lebih baik di tahun-tahun selanjutnya adalah dengan meningkatkan efisiensi di dalam perusahaan dengan cara menekan pengeluaran kas yang digunakan untuk membayar setiap beban yang terjadi. Terlebih pengeluaran untuk membayar beban lainnya yang berhubungan dengan aktivitas operasi. Perusahaan harus mampu mengelola setiap pengeluaran kas untuk aktivitas operasi dengan sebaik-baiknya.

\section{c. Cash Flow to Net Income Ratio}


Dapat dilihat dari tahun 2011 sampai dengan 2013 terjadi fluktuatif rasio pada perusahaan yang bernilai negatif. Hal Ini menandakan bahwa perusahaan mempunyai kinerja yang tidak baik dalam menghasilkan kas. Perusahaan tidak mampu menghasilkan sumber daya kas yang lebih besar dari jumlah laba bersih yang diperolehnya.

\section{d. Quality of Sales Ratio}

Pada perhitungan diatas adanya penurunan rasio pada tahun 2012. Menandakan kas yang dihasilkan dari penjualan berkurang. Pada tahun 2013 mengalami kenaikan, ini menunjukan bahwa kas yang dihasilkan dari penjualan meningkat.

\section{e. Quality of Income Ratio}

Perbedaan penghasilan atas dasar akrual dengan penghasilan atas dasar kas yang diperoleh perusahaan antara tahun 2011 ke tahun 2012 menunjukan kecenderungan yang menurun. Tetapi penurunan ini cukup material, karena perusahaaan mengalami peningkatan laba operasi di tahun 2012 tetapi tidak diiringi dengan peningkatan jumlah arus kas yang dihasilkan oleh aktivitas operasi perusahaan. Peningkatan ini disebabkan oleh kenaikan laba kotor atas penjualan yang berhasil dicapai perusahaan di tahun 2012. Walaupun beban usaha perseroan mengalami peningkatan seiring dengan bertambahnya penjualan, tetapi kenaikan ini masih ditutupi dengan peningkatan jumlah laba kotor yang lebih besar di tahun 2012 .

$$
\text { Pada tahun } 2012 \text { dan } 2013
$$

menunjukan kecenderungan yang meningkat. Tetapi peningkatan ini cukup material, karena perusahaan dapat meningkatkan jumlah arus kas yang dihasilkan oleh aktivitas operasi perusahaan tetapi mengalami penurunan laba operasi perusahaan di tahun 2013.
Peningkatan ini disebabkan oleh meningkatnya penerimaan pelanggan dari aktivitas operasi.

Berdasarkan uraian di atas, perusahaan mempunyai kualitas yang kurang memuaskan dalam kemampuannya megubah penghasilan atas dasar akrual menjadi arus kas bersih yang bersih yang dihasilkan oleh aktivitas operasi, karena kualitas penghasilan yang baik adalah kenaikan laba operasi perusahaan diiringi dengan kenaikan jumlah arus kas yang dihasilkan oleh aktivitas operasi perusahaan.

\section{f. Cash Return on Assets Ratio}

Dari pehitungan dari tahun 2011 sampai dengan tahun 2013 terjadi peningkatan dan penurunan dari segi pengembalian (return) atas seluruh aktiva yang telah digunakan selama tahun berjalan dengan rasio bernilai negatif. Hal ini menunjukan perusahaan memiliki kinerja yang kurang baik dalam menghasilkan kas selama tahun berjalan. Dengan demikian, secara keseluruhan perhitungan rasio ini telah mempengaruhi profitabilitas perusahaan.

\section{g. Cash Return on Stockholder's Equity Ratio}

Analisis dari tahun 2011 sampai dengan tahun 2013 di atas terjadi flukutuatif. Hal ini menunjukan bahwa dalam memberikan keuntungan berupa kas kepada para pemegang saham, perusahaan tidak mampu memberikan return dalam bentuk kas kepada para pemegang saham dari arus kas yang dihasilkan oleh aktivitas operasi dengan rasio bernilai negatif. Dengan demikian, perusahaan mempunyai kemampuan yang tidak baik dalam menjamin setiap hutang-hutangnya, baik hutang jangka pendek maupun hutang jangka panjang. 
Dilihat dari segi likuiditas, perusahaan tidak mampu menjamin setengah dari hutang jangka pendeknya hanya dengan mengandalkan arus kas bersih yang dihasilkan oleh aktivitas operasi. Perusahaan juga memiliki kemampuan yang kurang baik dalam memberikan return, berupa deviden kas, kepada para pemegang saham.

\subsection{Pola Arus Kas}

Dilihat dari laporan arus kas PT Indomobil Sukses Internasional Tbk dari tahun 2011 sampai dengan 2013, menghasilkan arus kas dengan pola arus kas negatif dari aktivitas operasi. Pola arus kas ini menggambarkan bahwa perusahaan tidak menghasilkan arus kas yang cukup untuk memelihara kemampuan operasi perusahaan. PT Indomobil Sukses Internasional Tbk. memiliki pola negatif yang berarti perusahaan ini adalah perusahaan yang kinerjanya dapat dipercaya sebab memiliki uang kas yang lebih yang dapat digunakan untuk melakukan investasi. PT Indomobil Sukses Internasional Tbk. melakukan aktivitas investasi dengan melakukan pembelian asset tetap.

Arus kas dari aktivitas pendanaan umumnya berasal dari penerimaan dan pengeluaran kas sehubungan dengan transaksi pendanaan jangka panjang dengan pemegang saham perusahaan dan kreditur. Arus kas dari aktivitas pendanaan PT Indomobil Sukses Internasional Tbk. memliki pola positif yang berarti perusahaan tidak memiliki uang kas lebih yang digunakan untuk membayar pinjaman jangka pendek dan pembayaran deviden kepada pemegang saham.

Berdasarkan pola arus kas PT Indomobil Sukses Internasional Tbk menunjukan aktivitas operasi dan investasi bernilai negatif serta aktivitas pendanaan bernilai positif berarti perusahaan memiliki kinerja yang kurang dapat dipercaya karena perusahaan tidak menggunakan kas yang dihasilkan dari operasi untuk pembelian aktiva tetap dan membayar hutang atau membayar deviden tetapi mengandalkan pinjaman kas dari luar.

Dilihat dari pola arus kas PT Indomobil Sukses Internasional Tbk untuk tahun 2011 sampai dengan tahun 2013, arus kas dari aktivitas operasi perusahaan menghasilkan net cash yang bernilai negatif. Dengan demikian, kondisi keuangan PT Indomobil Sukses Internasional Tbk adalah tidak baik. Arus kas dari kegiatan investasi memberikan hasil yang negatif, maka dapat dikatakan kondisi keuangan PT Indomobil Sukses Internasional Tbk adalah baik. Arus kas masuk yang dihasilkan perusahaan dari aktivitas pendanaan menghasilkan jumlah yang lebih besar dibandingkan dengan arus kas keluar yang dibayarkan perusahaan kepada pihak ketiga. Hal ini disebabkan perusahaan banyak melakukan pinjaman jangka panjang dari bank untuk mengembangkan usahanya, seperti untuk mendirikan cabang baru bagi usaha yang tergabung dalam PT Indomobil Sukses Internasional Tbk. Oleh karena itu, arus kas pendanaan perusahaan menghasilkan jumlah arus kas bersih yang bernilai positif dari aktivitas pendanaan. Dari penjelasan ketiga pola arus kas di atas, maka dapat disimpulkan bahwa kondisi keuangan PT Indomobil Sukses Internasional Tbk, secara umum dalam kondisi kurang baik.

\section{Penutup}

Berdasarkan hasil analisis laporan arus kas PT Indomobil Sukses Internasional Tbk pada Bab IV, maka dapat diambil beberapa kesimpulan sebagai berikut: 
1. Dilihat dari pola arus kas PT Indomobil Sukses Internasional Tbk untuk tahun 2011 sampai dengan tahun 2013, arus kas dari aktivitas operasi perusahaan menghasilkan net cash yang bernilai negatif. Dengan demikian, kondisi keuangan PT Indomobil Sukses Internasional Tbk adalah tidak baik. Arus kas dari kegiatan investasi memberikan hasil yang negatif, maka dapat dikatakan kondisi keuangan PT Indomobil Sukses Internasional Tbk adalah baik. Arus kas masuk yang dihasilkan perusahaan dari aktivitas pendanaan menghasilkan jumlah yang lebih besar dibandingkan dengan arus kas keluar yang dibayarkan perusahaan kepada pihak ketiga. Hal ini disebabkan perusahaan banyak melakukan pinjaman jangka panjang dari bank untuk mengembangkan usahanya, seperti untuk mendirikan cabang baru bagi usaha yang tergabung dalam PT Indomobil Sukses Internasional Tbk. Oleh karena itu, arus kas pendanaan perusahaan menghasilkan jumlah arus kas bersih yang bernilai positif dari aktivitas pendanaan. Dari penjelasan ketiga pola arus kas di atas, maka dapat disimpulkan bahwa kondisi keuangan PT Indomobil Sukses Internasional Tbk, secara umum dalam kondisi kurang baik.

2. Evaluasi terhadap arus kas mencermnkan knerja perusahaan PT ndomobil sukses nternasonal tbk. Tidak sehat, hal ini dapat dilihat:

a. Berdasarkan liquidity ratios, perusahaan mempunyai kemampuan yang kurang baik dalam membayar kewajiban lancarnya dari tahun 2011 sampai dengan tahun 2013. Dengan hasil analisis laporan arus kas, dimana perusahaan tidak mampu membayar kewajiban lancarnya, hanya dengan menggunakan arus kas yang dihasilkannya dari aktivitas operasi perusahaan. Perusahaan juga belum memiliki tingkat likuiditas yang memadai karena perusahaan tidak mampu membayar deviden kepada para pemegang saham hanya dengan mengandalkan jumlah arus kas bersih yang dihasilkan oleh aktivitas operasinya. Dapat disimpulkan bahwa perusahaan tidak mampu dalam menjamin setiap kewajiban lancarnya untuk membayar deviden dalam bentuk riil (secara kas) secara matematis.

b. Berdasarkan solvency ratios, pinjaman perusahaan kepada pihak ketiga (kreditor) mengalami fluktuatif dengan hasil rasio negatif. Perusahaan tidak dapat menutup hampir setengah dari seluruh kewajiban lancarnya hanya dengan mengandalkan arus kas yang dihasilkan melalui aktivitas operasi pada tanggal jatuh temponya. Dapat dikatakan secara keseluruhan perusahaan memiliki tingkat solvabilitas yang tidak baik. Struktur modal perusahaan belum cukup efektif dan efisien. Pihak manajemen 


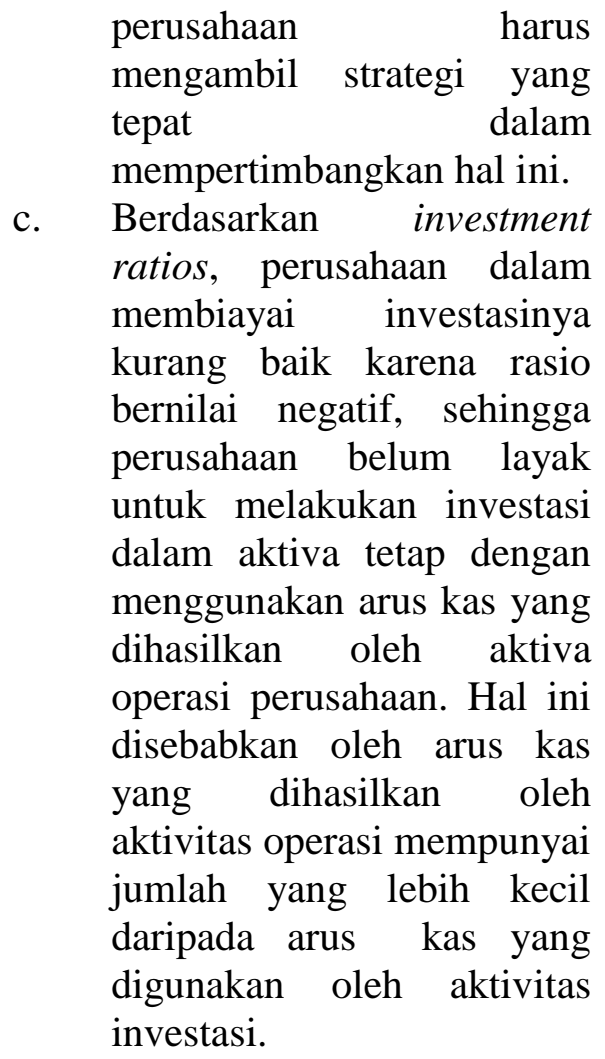

d. Berdasarkan cash flow return ratios, laba bersih yang dihasilkan perusahaan di tahun 2012 dan 2013 mengalami penurunan. Penurunan ini pun mengindikasikan bahwa kinerja perusahaan dalam menghasilkan laba juga menurun. Kinerja perusahaan dalam memberikan return kepada pihak-pihak yang berkepintingan pun cenderung menurun, dilihat dari hasil rasio yang didapatkan adalah negatif. Hal ini disebabkan oleh pihak manajemen perusahaan tidak mampu menekan biaya operasi yang dikeluarkan. Analisis laporan arus kas memberikan kesimpulan bahwa kinerja perusahaan mengalami kemunduran. Kemunduran ini disebabkan oleh efisiensi pihak manajemen dalam mengelola sumber daya kas, terutama dari segi pengeluaran untuk membayar beban yang bersangkutan dengan operasi perusahaan dan juga mempunyai kemampuan yang kurang baik dalam menagih kas dari setiap transaksi penjualan yang terjadi. Kemunduran dalam jumlah yang signifikan telah memberikan isyarat kepada para investor dan kreditor bahwa perusahaan memang meiliki kemampuan yang kurang baik dalam memberikan return.

Dengan evaluasi terhadap laporan arus kas dapat membantu pihak manajemen perusahaan dalam melakukan pengambilan keprutusan, yang berkaitan dengan kelangsungan hidup PT Indomobil Sukses Internasional Tbk.

\section{Daftar Pustaka}

Andika Febriani. 2009. Analisis Kemampuan Prediksi Laporan Arus Kas Dan Kinerja Perusahaan Berdasarkan Rasio Keuangan: Studi Kasus Pada PT Excelmivdo Pratama Tbk. Skripsi Fakultas Ekonomi Universitas Khatolik Indonesia Atmajaya Jakarta.

Buku pedoman seminar S1 (2014). Universitas Pakuan Fakultas Ekonomi, Bogor.

Fegi Syahputra. Analisis Kinerja Keuangan Dengan Menggunakan Laporan Arus Kas Perusahaan Manufaktur Yang Terdaftar Di BEI. Skripsi Fakultas Ekonomi Universitas Negeri Padang. 
Hery.(2009). Akuntansi keuangan menegah 1.Jakarta: Bumi Aksara.

Ikatan Akuntan Indonesia. (2009). Standar akuntansi keuangan per 1 Juli 2009. Jakarta: Salemba Empat.

Indrianto, Nur., Bambang Supomo, 2009. Metodologi Penelitian Bisnis Untuk Akuntansi Dan Manajemen, Edisi Pertama. Yogyakarta:BPFE Yogyakarta

Jumingan. (2008). Analisis Laporan Keuangan. Bumi Aksara, Surakarta.

Kusumadiyanto. 2006. Analisis Laporan Keuangan Untuk Menilai Kinerja Perusahaan Pada Kelompok Industri Rokok. Skripsi Fakultas Ekonomi Universitas Widyatama Bandung.

Maria Carolina Somi. 2007. Analisa Laporan Keuangan Untuk Mengevaluasi Kinerja Keuangan Pada PT Hero Supermarket Tbk. Skripsi Fakultas Ekonomi Universitas Khatolik Indonesia Atmajaya Jakarta.

Kieso, Donald E., Jerry J. Weygandt, \& Paul D. Kimmel. (2002). Accounting Principles ( $6^{\text {th }}$ edition). New York: John Wiley \& Sons Inc.

Plewa, Franklin J. \& George T. Friedlob. (1995). Understanding Cash Flow. Toronto: John Wiley \& Sons Inc.

PT Indomobil Sukses Internasional, Tbk. Laporan Tahunan 2012 Indomobil. Jakarta: Indomobil.

PT Indomobil Sukses Internasional, Tbk. Laporan Tahunan 2013 Indomobil. Jakarta: Indomobil.

Rudianto. (2009). Pengantar akuntansi: Konsep dan teknik penyusunan laporan keuangan. Jakarta: Erlangga.

Simamora, H. (2000). Akuntansi: Basis pengambilan keputusan bisnis, jilid 2. Jakarta: Salemba Empat.
Stice, J.D., Stice, E.K ., \& Skousen, K.F. (2009). Akuntansi keuangan, buku 1. (Penerjemah Ali Akbar). Jakarta: Salemba Empat. (Buku asli diterbitkan 2007).

Stice, Stice \& Skousen. (2007). Intermediate Accounting $16^{\text {th }}$ Edition. South Western College Publishing, Thomson Learning, Inc. Sutrisno. (2009). Manajemen Keuangan Teori, Konsep dan Aplikasi. Ekonisia, Yogyakarta.

Vira Aprilianti. 2007. Analisis Laporan Arus Ka Sebagai Salah Satu Penunjang Penilaian Kinerja Keuangan Pada PT Gudang Garam Tbk. Skripsi Fakultas Ekonomi Universitas Gunadarma Depok

Warren, C., Reeve, J., Duchac, J. (2007). Principle of Accounting $22^{\text {rd }}$ Edition. South Western: Thomson 